\title{
Marketing performance of bread and cake small and medium business with competitive advantage as moderating variable
}

\author{
Muhartini Salim $^{a^{*}}$, Fachri Eka Saputra ${ }^{a}$, Rina Suthia Hayu ${ }^{a}$ and Muhammad Rahman Febliansa ${ }^{b}$
}

${ }^{a}$ University of Bengkulu, Bengkulu, Indonesia

${ }^{b}$ University of Dehansen, Bengkulu, Indonesia

\section{H R O N I C L E}

Article history:

Received: September 28, 2020

Received in revised format:

October 102020

Accepted: October 20, 2020

Available online:

October 20,2020

Keywords:

Market Orientation

Product Innovation

Competitive Advantage

Marketing Performance

\section{Introduction}

Small and Medium Business (UKM) can survive in the business competition through great concern on marketing aspects. UKM owners should know and understand what the consumers need and what happens in the market as well as how the business surrounding changes. UKM's marketing is indirectly influenced by the pressure from business competitors. Often the marketing performance factor comes in hand to measure the effects and company strategies based on the marketing aspect. According to Hitt et al. (1998), marketing performance is defined as "a company's or organization's ability to transform in order to encounter the challenges due to the environmental changes in long term perspective". Marketing performance is a concept to measure the market achievement that has been obtained by a product of a company. In general, company performance can be seen in marketing performance. If marketing performance increases, company performance increases as well. The success of a company displayed by marketing performance is the implementation of a strategy. All the strategies are expected to be able to increase marketing performance. Vargo and Lusch (2008) stated that marketing performance embraces the selling, net profit, market share and overall performance. This article refers to the marketing performance theory from Gao (2010): comparison of performance to the goal is formulated from a market strategy. Business competition in marketing the products is not only based on product qualities but also based on strategies such as market orientation and product innovation. Market orientation and product innovation can be used as one of the strategies to reach a competitive advantage. Bharadwaj et al. (1993) state that "company culture focuses the market orientation in strengthening competitive advantage to

\footnotetext{
* Corresponding author.

E-mail address: muhartinisalim@unib.ac.id (M. Salim) 
increase marketing performance". Drucker (2014) suggest that "entrepreneurship orientation as the nature, character or characteristics attached in someone who has the spirit to make his innovative ideas come true in real business worlds and is able to develop it well". A company applies the market orientation means that it must have competitive quality products. Quality products attract consumers and will create a great perception of consumers' minds on the products and it finally increases the selling. The increasing sales in the company will increase the performance (Menon et al., 1997). Kotler and Keller (2015) define innovation as any goods, services, and ideas that are considered as something new. The companies that can formulate and apply the right innovation strategies in both internal and business scope will be able to increase the competitive capacity. Thus, management shall make the right decision on the shape and model of innovation strategies (Zahra et al., 2000). Porter (1998) explains that "competitive advantage as the capability of a company to gain profit more than that the competitor company with the same product can obtain". While Noe et al. (2006) suggest the competitive advantage is "company capability to make its products and services gain more acknowledgment from the consumers compared with other competitor companies". This will bring the company to reach its right targets and goals. A similar opinion is stated by Contador et al. (2012) that define competitive advantage as "the highest position that encourages the company to be competitive compared to its competitor companies". Kotler and Amstrong (2013) state that "competitive advantage as the benefits gained over the competitors through offering more values to the consumers in the form of lower prices or higher prices with more benefits included in the products". Competitive advantage also comes from any activities such as product designing, production, distribution, delivery, and support. There have been many studies that indicate market orientation and product innovation affect marketing performance partially. Market orientation influences marketing performance (Pulendran et al., 2003; Shoham et al., 2005; Sin et al., 2000; Rahmawati et al., 2019). If market orientation is performed effectively according to the customers' needs and wishes, it will influence the marketing performance. Product innovation influences marketing performance (Akgün et al., 2009; Maupa et al., 2017; Ogi et al., 2016). Product innovation that can create new product is very important in business and it will influence marketing performance.

This study uses four (4) variables: one (1) dependent variable, two (2) independent variables, and one (1) moderating variable. The dependent variable is the marketing performance by Gao (2010). Independent variables are market orientation by Slater $\&$ Narver (1995) and product innovation is adopted by Freeman (1982). The moderating variable is competitive advantage by Bharadwaj et al. (1993). UKMs for bread and cake industry are growing in Bengkulu. These UKMs focus their products on bread and cake. One of the popular cake products is Bay Tat cake. This is a traditional cake from Bengkulu. According to Maflahah (2012), traditional food is the food popular and consumed a lot within a community with its unique taste and flavor. UKMs nowadays seem neither creative nor innovative. Insufficient knowledge of market demands, small capita, and lack of labor force for production become the major problems. On the other hand, the competition gets stronger that indirectly influence marketing performance. it was the marketing performance that influences the business agents of bread and cake UKMs in Bengkulu city. To create good marketing performance, it is necessary to investigate the influencing factors. This study aims to analyze the marketing performance of bread and cake UKMs in Bengkulu city. The competitive advantage became the moderating variable because the author intended to see whether this variable could strengthen or weaken the influence of market orientation and product innovation partially on marketing performance. Competitive advantage variable was always used as independent and mediating variable in the previous researches such as in (Yacob et al., 2020). Since there have not been any similar studies using competitive advantage as the moderating variable, this current study is expected to be the novelty.

This current study is significant because the findings will contribute to the strategies for bread and cake UKMs to increase their marketing performance. Based on the reasons, the author put her great interest in this current study with the title "marketing performance of bread and cake UKMs with competitive advantage as the moderating variable in Bengkulu city".

\section{Theoretical background and hypotheses development}

\subsection{Marketing Performance}

Marketing performance is an indicator to measure the marketing achievement of a company. Every company needs to know its achievement as the representation of its success in market competition. Business needs internal support such as innovation and external support such as market searching, promotion, and technology (Xuan et al., 2020). The company's success displayed by the marketing performance is the implementation of strategies used by the company in selling its products in the market. Ferdinand (2003) states that "marketing performance is a frequently used factor to measure the impact of strategies existing in the companies". Organization performance is "the results or outcomes of an organization which is later measured and compared to the company's target" (Jahanshahi, 2012). If UMKMs' marketing performance can always increase with their local products then it will increase the chance for foreign market (Santra et al., 2020). The marketing performance variable in this study refers to the study of Song and Parry (2009) that consists of three (3) indicators: selling growth, consumer growth, and selling volume.

\subsection{Market Orientation}

According to Jaworski and Kohli (1993), market orientation is "company orientation based on how to satisfy consumers' needs and wishes". A company can sustain its existence in tight business competition. Markets should be managed by investigating their demands and consumers' needs that goods and services could satisfy them. Market orientation is the main factor or marketing performance (Julian, 2010). 
Baker and Sinkula (2009) believe that "a company that has market orientation will have a faster revision foundation; this can be seen from company's successful products, profitability, market share, and continuous competitive advantage". Slater \& Narver (1995) suggest that "a business entity can gain maximum potential market orientation if the business orientation is right, following the design and organization structure". Market orientation in this study refers to Narver \& Slater (1990) with three (3) indicators: consumer orientation, competitor orientation, and inter-functional coordination. Consumer and competitor orientation include any activities related to any information on buyers and competitors in the target market and activities that spread through business while inter-functional coordination is based on the information of consumers and competitors that include the coordinated business entities.

\subsection{Product Innovation}

Consumers in general wish to have innovative products that fulfill their desire. Porter (1998) explains that to expand a business, product innovation is needed to implement. UKMs will progress better if they can innovate new products. Competition gets higher and consumers become more selective in buying products, they demand the company to be more innovative in creating a product. In the other words, companies need to offer new products which are comparably better than those of the competitors. According to Tjiptono (2011) "New products hold an important role in increasing the company's profitability while innovation process plays its role as cost deduction strategy". Freeman (1982) suggests product innovation as the process that includes technical design, research and development, manufacture, management, and any commercial activities involved in marketing new products or upgraded products. This study used product innovation indicators adopted by Freeman (1982):

a. Culture of innovation is the organization culture existing in a company to always create new products.

b. Technical innovation is innovation in the process of a company creating new products.

c. Service innovation is the process when a company serves its consumers or customers.

\subsection{Competitive Advantage}

A company to gain its competitive advantage needs to hire employees with unique skills. According to (Bharadwaj et al., 1993, p. 83-84), competitive advantage is the implementation of the strategy by utilizing all company's resources. Companies will have a competitive advantage if they can apply strategy to create value which at the same time cannot be created by potential competitors (Ferdinand, 2003). This research used a competitive advantage indicator that was adopted from Bharadwaj et al. (1993): uniqueness, rarity, uneasily imitated, not easily changeable, and competitive price.

\subsection{Market orientation influences Marketing}

Companies to encounter the competitors should perform the marketing effectively: ensure to provide the goods and services that satisfy consumers' needs and wishes. Uncles (2000) believes that market orientation can be defined as any process and activities involved in creating and satisfying consumers by analyzing consumers' needs and wishes. Needs will increase and reach their satisfaction if the goods and services can meet consumers' desires. The increasing needs and wishes from the consumers will increase the selling product quantity in a company, and this indicates that marketing performance runs effectively. Previous studies show that market orientation has a positive influence on marketing performance (Baker \& Sinkula, 2009; Julian, 2010; Kara et al. 2005; Manzano, et al. 2006; Susanto, 2012). This means that if market orientation increases, marketing performance will increase as well.

Based on the above theories and explanations, the hypothesis in this study is:

$\mathrm{H}_{1}$ : Market orientation positively influences marketing performance.

\subsection{Product Innovation influences Marketing Performance}

Product innovation will create several product designs that increase alternative selections, benefits, or values for consumers resulting in an increase in the expected product quality (Prajogo \& Sohal, 2001:85). Product innovation in the business world is very essential since it can create novelty of a product from its looks, system, process, and other aspects. An innovative and unique product offered in the market will gain high performance (Salim et al. 2020). Innovation is someone's creativity which according to Bharadwaj et al. (1993) has an important influence on marketing performance. Previous studies show that product innovation has positive influences on marketing performance (Herman et al., 2018; Jajja et al., 2017; Killa, 2014; Rosli \& Sidek, 2013). This means that if product innovation increases, marketing performance will increase as well.

Based on the above theories and explanations, the hypothesis in this study is.

\section{$\mathrm{H}_{2}$ : Product Innovation positively influences Marketing Performance.}

\subsection{Competitive Advantage as the Moderating Variable}

Kotler and Amstrong (2013) state that "competitive advantage as the benefit gained over the competitors through offering more values to the consumers in the form of lower prices or higher prices with more benefits included in the products". The competitive advantage in this study acts as the moderating variable to see whether this variable could strengthen or weaken the influence of market orientation and product innovation partially on marketing performance 
Previous studies have not used a competitive advantage as a moderating variable. Therefore, the hypotheses in this study are:

$\mathrm{H}_{3}$ : Competitive advantage moderates the influence of market orientation on marketing performance.

$\mathrm{H}_{4}$ : Competitive advantage moderates the influence of product innovation on marketing performance.

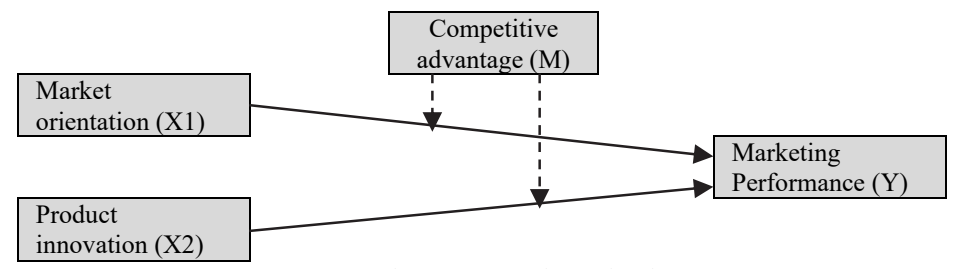

Fig. The proposed method

\section{Methodology}

\subsection{Type of Study}

This study is a survey study, and the information was gathered from the respondents through a questionnaire that was distributed online.

\subsection{Population and Sampling Techniques}

The population in this study is the owners and employees of bread and cake UKMs in Bengkulu city with the total respondents of 40 owners and 110 employees. The sampling technique was done by census and it was obtained 4 UKM owners and 40 employees, thus the total respondents were 80 respondents.

\subsection{Validity and Reliability Tests}

\subsubsection{Validity Test}

This study used convergent validity with a reflective indicator measured by loading factor (correlation between item score/ component score with construct score). The loading factor of indicators measures the construct. Hair et al. (2010) state that "loading factor score bigger than 0.30 is considered fulfilling minimum level; loading factor score $=0.40$ is considered better and fit with the rule of thumb used by the researcher, and loading factor $>0.50$ is considered significant. Rule of thumb used for convergent validity is outer loading $>0.70$, communally $>0.50$ and Average Variance Extracted (AVE) $>0.50$ (Chin, 1998). The result of the validity test can be seen in Table 1 .

Table 1

Summary of Validity test result

\begin{tabular}{|c|c|c|c|}
\hline Item & Factor Loading & AVE & Communality \\
\hline Market Orientation & & 0.697 & 0.51 \\
\hline Consumer Orientation & 0.845 & & \\
\hline Competitor Orientation & 0.817 & & \\
\hline Inter-Functional Coordination & 0.843 & & \\
\hline Product Innovation & & 0,763 & 0.649 \\
\hline Culture of innovation & 0.858 & & \\
\hline Technical innovation & 0.932 & & \\
\hline Service innovation & 0.827 & & \\
\hline Marketing Performance & & 0.702 & 0.555 \\
\hline Selling Growth & 0.854 & & \\
\hline Consumer growth & 0.744 & & \\
\hline Selling volume & 0.906 & & \\
\hline Competitive Advantage & & 0.849 & 0.649 \\
\hline Uniqueness & 0.93 & & \\
\hline Rarity & 0.925 & & \\
\hline Uneasily imitated & 0.921 & & \\
\hline Not easily changeable & 0.92 & & \\
\hline Competitive price & 0.911 & & \\
\hline
\end{tabular}

As can be seen in Table 1, the entire variables have a communally score of $>0.5$ and an Average Variance Extracted (AVE) score of $>0.5$. This fits the convergent validity criterion; thus, all indicators are considered valid and able to be used for further analysis. 


\subsection{Reliability}

The reliability test in PLS can use two (2) methods: Cronbach's alpha and composite reliability. The rule of thumb of alpha score or composite reliability shall be bigger than 0.7 , even though 0.6 is still accepted (Hair et al., 2010). The result of the reliability test can be seen in table 2 .

Table 2

Summary table of reliability Test result

\begin{tabular}{lcc}
\hline Item & Cronbach Alpha & Composite Reliability \\
\hline Market Orientation & 0.79 & 0.873 \\
Product Innovation & 0.844 & 0.906 \\
Marketing Performance & 0.787 & 0.875 \\
Competitive Advantage & 0.956 & 0.966 \\
\hline
\end{tabular}

The result in Table 2 indicates Cronbach's alpha and composite reliability for each variable bigger than 0.7. Thus, it can be concluded that the instrument used in this study reliable.

\subsection{Method of Analysis}

The data analysis used in this study is inferential statistical analysis: Structural Equation Modeling (SEM) which is operated by the Partial Least Square program (PLS): SmartPLS 3.2.9.

\section{The result of Data Analysis}

The data that had been tested for validity and reliability were then tested by SEM through SmartPLS 3.2.9 for hypothesis tests. The result of data processing for SmartPLS 3.2.9 can be seen in Fig. 2.

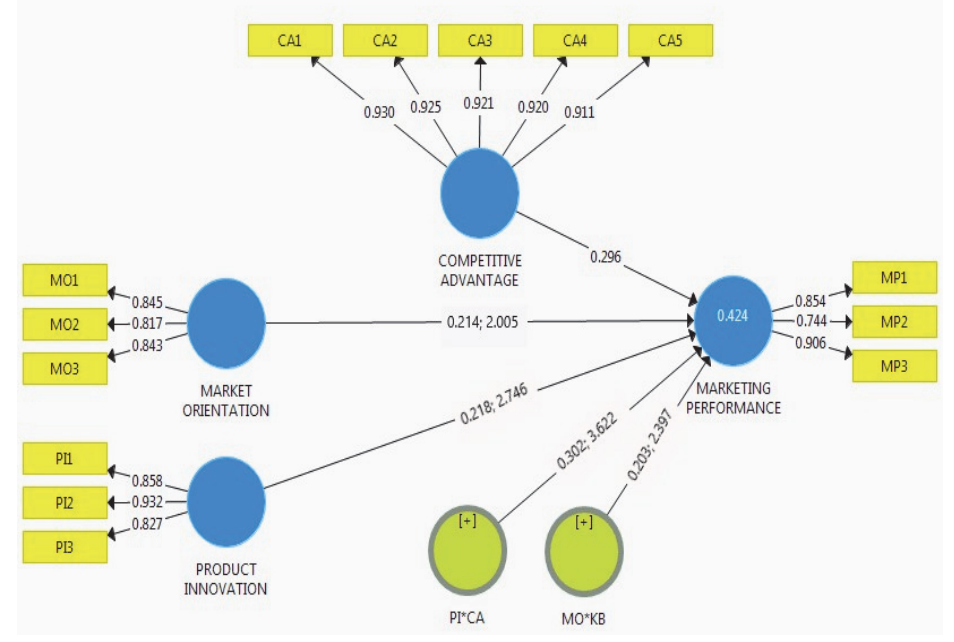

Fig. 2. Summary Figure of structural Model Output

Source: The Data was Processed (2020)

Hypothesis 1: Market orientation positively influences the Marketing Performance.

The result of the study obtained a coefficient beta of 0.214 and a $t$ score of 2.005. $t$ score $>1.64$ (one tailed-hypothesis) indicated that market orientation has a positive influence on marketing performance.

Hypothesis 2: Product Innovation positively influences Marketing Performance.

The result of the study obtained a coefficient beta of 0.218 and a $t$ score of 2.746. $t$ score $>1.64$ (one tailed-hypothesis) indicated that product innovation has a positive influence on marketing performance.

Hypothesis 3: Competitive Advantage as the moderating variable of market orientation influence on marketing performance.

The result of the study obtained $t$ score of 2.397. $t$ score $>1.96$ (two tailed-hypothesis caused by moderation) indicated that competitive advantage moderates (strengthens) market orientation influence on marketing performance.

Hypothesis 4: Competitive Advantage as the moderating variable of product innovation influence on marketing performance. 
The result of the study obtained $t$ score of 3.622. $t$ score $>1.96$ (two tailed-hypothesis caused by moderation) indicated that competitive advantage moderates (strengthens) product innovation influence on marketing performance.

\section{Discussion}

This focuses on hypotheses testing in the objective of this study.

\subsection{Market orientation positively influences marketing performance}

The result of this study found that market orientation positively influences marketing performance. This means that the stronger the market orientation, the more marketing performance increases. This result is in line with previous studies from (Hussain et al., 2019; Kara et al., 2005; Sutapa et al., 2017; Zhang \& Zhu, 2016). Companies with market orientation are led by their excellent knowledge about consumers' needs in the current time and the future due to their capability to offer the solution for any demands and definitely better than that offered by the competitors (Slater \& Narver, 2000). Gunarathne (2015) said that "Market orientation can be defined as the organization culture where employees put their commitment to continuously create excellent consumer value or as the series of marketing activities that leads to good performance". The owners of UKMs in Bengkulu city can increase the marketing performance if they concern about consumer orientation, competitor orientation, and inter-functional coordination. Consumer orientation includes any activities involved to gather information related to consumers' needs and wishes. Competitor orientation is the company's willingness to observe competitors' strategies. Inter-functional coordination means that company leaders are willing to spread the whole information of the organization.

\subsection{Product Innovation positively influences marketing performance}

The result of this study found that product innovation positively influences marketing performance. this means that the stronger the product innovation the more marketing performance increases. This result is in line with previous studies from (Aksoy, 2017; Al Saed \& Abu Saleh, 2017; Zaefarian et al. 2017). Product innovation is an important instrument that is used by an organization to change and build significant capability to stay competitive in easily change business worlds (Dougherty, 1990). Any companies shall create innovations that will help/ support all efforts to increase and sustain products in target markets. According to Fossas-Olalla et al. (2015) "Successful product innovation will earn benefits, increase market share and have a positive impact on marketing performance". Small companies invest more in product innovation compared to what they do on process innovation (Cohen \& Klepper, 1996; Yin \& Zuscovitch, 1998). Companies need to apply the culture of innovation to success in product and innovative service aspects. Bread and cake UKMs in Bengkulu city can increase the marketing performance if they can always apply the innovation culture: the process to create new products and technological services to consumers. Product innovation can be done by modifying the existing products to create unique and new products with great quality.

\subsection{Competitive Advantage moderates (strengthens) market orientation influence on marketing performance}

The results are: 1. Competitive Advantage moderates (strengthens) market orientation influence on marketing performance. This means that competitive advantage (uniqueness, rarity, uneasily imitated, not easily changeable, and competitive price) will strengthen product innovation influence on marketing performance

This result is not in line with any previous studies since there have not been any studies that investigated this topic.

Porter (1990) said that "one of the challenges for companies is how to achieve competitive advantage". Companies in handling business will not be able to not deal with a competitive advantage. They can only survive the business if they have a competitive advantage. This study indicated that competitive advantage strengthens the influence. This means that competitive advantage will increase marketing performance. Bread and cake UKMs in Bengkulu city shall have a competitive advantage that the marketing increases as well. competitive advantage can be in forms of uniqueness, rarity, uneasily imitated, not easily changeable, and competitive price.

\section{Conclusion}

1. This study found: 1 . Market orientation influences the marketing performance. The marketing performance of bread and cake UKMs in Bengkulu city can be increased if the owners perform consumer orientation, competitor orientation, and inter-functional coordination. This study is in line with several researches (Baker \& Sinkula, 2009; Hussain et al., 2019; Kara et al., 2005). However this study is also in contradiction with several researches that suggest market orientation does not any influence in marketing performance (Han et al., 1998; Johnson et al., 2009).

2. Product innovation influences marketing performance. The marketing performance of bread and cake UKMs in Bengkulu city can be increased if the UKMs always apply innovation culture, a process to create new products and technological services to consumers. This study is in line with other several researches (Julian, 2010; Rosli \& Sidek, 2013; Zhang \& Zhu, 2016). In the other hand, this study is in contradiction with several researches that believe product innovation does not have significant influence on marketing performance (Cillo et al., 2010). 
3. Competitive advantage moderates the influence of market orientation and product innovation on marketing performance. Bread and cake UKMs in Bengkulu city shall have the competitive advantage such as uniqueness, rarity, uneasily imitated, not easily changeable, and competitive price. The result of this study is not supported by any previous research since there was no similar research in the past that investigated this topic.

The business entities in this study have several kinds of products. Thus, the further research should consider the uniformity of the companies. The samples shall be increased and cover more than one region. Besides, the further study should determine the size, characteristic, and length of operation of business entities.

\section{References}

Akgün, A. E., Keskin, H., \& Byrne, J. (2009). Organizational emotional capability, product and process innovation, and firm performance: An empirical analysis. Journal of Engineering and Technology Management - JET-M, 26(3), $103-130$.

Aksoy, H. (2017). How do innovation culture, marketing innovation and product innovation affect the market performance of small and medium-sized enterprises (SMEs)? Technology in Society, 51, 133-141.

Al Saed, R., \& Abu Saleh, M. (2017). Market Orientation Product Innovation and performance in Small Firms in Sharjah, UAE. Research Journal of Social Science \& Management, 7(3), 31-38.

Jahanshahi, A. A., Rezaei, M., Nawaser, K., Ranjbar, V., \& Pitamber, B. K. (2012). Analyzing the effects of electronic commerce on organizational performance: Evidence from small and medium enterprises. African Journal of Business Management, 6(22), 6486-6496.

Baker, W. E., \& Sinkula, J. M. (2009). The complementary effects of market orientation and entrepreneurial orientation on profitability in small businesses. Journal of Small Business Management, 47(4)

Bharadwaj, S. G., Varadarajan, P. R., \& Fahy, J. (1993). Sustainable competitive advantage in service industries: a conceptual model and research propositions. Journal of marketing, 57(4), 83-99.

Cillo, P., De Luca, L. M., \& Troilo, G. (2010). Market information approaches, product innovativeness, and firm performance: An empirical study in the fashion industry. Research Policy, 39(9), 1242-1252.

Cohen, W. M., \& Klepper, S. (1996). Firm size and the nature of innovation within industries: The case of process and product R\&D. Review of Economics and Statistics, 78(2), 232-243. https://doi.org/10.2307/2109925

Contador, J. C., Ferreira, A. A., Simões, S. A., \& Souza, W. J. (2012). It outsourcing: methodology for selecting suppliers criterion for competitive advantage. JISTEM-Journal of Information Systems and Technology Management, 9(1), 123-146.

Dougherty, D. (1990). Understanding new markets for new products. Strategic Management Journal, 11, 59-78.

Drucker, P. F. (2014). Trade from the World Lessons Economy. 73(1), 99-108.

Ferdinand, A. (2003). Manajemen Pemasaran: Sebuah Pendekatan Stratejik. Research Paper Series.

Fossas-Olalla, M., Minguela-Rata, B., López-Sánchez, J. I., \& Fernández-Menéndez, J. (2015). Product innovation: When should suppliers begin to collaborate? Journal of Business Research, 68(7), 1404-1406.

Freeman, D. (1982). Observing teachers: Three approaches to in-service training and development. Tesol Quarterly, 16(1), $21-28$.

Gao, Y. (2010). Measuring marketing performance: a review and a framework. The Marketing Review, 10(1), 25-40.

Gunarathne, U. (2015). Measurement Model of the Market Orientation: New Theoretical Framework NEWMKTOR Model. International Journal of Management and Commerce Innovations, 3(1), 255-263.

Hair, J. R., Black, W. C., Babin, B. J., \& Anderson, R. E. (2010). Multivariate Data Analysis (Seven Edit). Pearson Prentice Hall.

Han, J. K., Kim, N., \& Srivastava, R. K. (1998). Market orientation and organizational performance: Is innovation a missing link? Journal of Marketing, 62(4), 30-45.

Herman, H., Hady, H., \& Arafah, W. (2018). The Influence of Market Orientation and Product Innovation on the Competitive Advantage and Its Implication toward Small and Medium Enterprises (Ukm) Performance. International Journal of Science and Engineering Invention, 4(08), 8-21.

Hitt, M. A., Keats, B. W., \& DeMarie, S. M. (1998). Navigating in the new competitive landscape: Building strategic flexibility and competitive advantage in the 21 st century. Academy of Management Executive.

Hussain, J., Khan, A. A., \& Khan, M. I. (2019). The effect of strategic orientations on organizational performance of SMEs: Empirical evidence from Pakistan. Journal on Innovation and Sustainability RISUS, 10(3).

Jajja, M. S. S., Kannan, V. R., Brah, S. A., \& Hassan, S. Z. (2017). Linkages between firm innovation strategy, suppliers, product innovation, and business performance: Insights from resource dependence theory. International Journal of Operations and Production Management, 37(8), 1054-1075.

Jaworski, B. J., \& Kohli, A. K. (1993). Market Orientation : Antecedents. Journal of Marketing, 57(July), 53-70.

Johnson, A. J., Dibrell, C., \& Hansen, E. (2009). Market orientation, innovativeness, and performance of food companies. Journal of Agribusiness, 27(1/2), 85-106. http://core.ac.uk/download/pdf/6620086.pdf

Julian, C. C. (2010). The market orientation-marketing performance relationship: the empirical link in international joint ventures. International Journal of Trade and Global Markets, 3(4), 414.

Kara, A., Spillan, J. E., \& DeShields, O. W. (2005). The effect of a market orientation on business performance: a study of smallsized service retailers using MARKOR scale. Journal of Small Business Management, 43(2), 105-118.

Killa, M. F. (2014). Effect of entrepreneurial innovativeness orientation, product innovation, and value co-creation on marketing performance. Journal of Research in Marketing, 2(3), 198. https://doi.org/10.17722/jorm.v2i3.73

Kotler, P., \& Amstrong, G. (2013). Prinsip-Prinsip Pemasaran Jilid I. In Erlangga.

Kotler, P., \& Keller, K. (2015). marketing management. In Small Business Marketing.

Maflahah, I. (2012). Desain kemasan makanan tradisional Madura dalam rangka pengembangan IKM. Agrointek, 6(2), $118-122$.

Manzano, J. A., Kuster, I., \& Via, N. (2006). Market Orientation and Inovation. Ship Technology Research, 53(4), $194-200$. 
Maupa, H., Brasit, N., Sulawesi, S., \& Jusni, I. (2017). The effects of business environment, market orientation, strategy, and product innovation on business performance in the real estate in makassar city Nur Naninsih. Scientific Research Journal (SCIRJ), 5(10), 51. www.scirj.org

Menon, A., Jaworski, B. J., \& Kohli, A. K. (1997). Product quality: Impact of interdepartmental interactions. Journal of the Academy of Marketing Science, 25(3), 187.

Narver, J. C., \& Slater, S. F. (1990). The effect of a market orientation on business profitability. Journal of Marketing, 54(4), $20-35$.

Noe, R. A., Hollenbeck, J. R., Gerhart, B. and Wright, P. M. (2006). Human Resource Management: Gaining a Competitive Advantage, 6th edn. (Boston, MA: McGraw-Hill Irwin). https://doi.org/10.1016/B978-0-12-812632-5.00017-3

Ogi, I., Massie, J., \& Lapian, A. (2016). PENGARUH ORIENTASI PASAR DAN INOVASI PRODUK TERHADAP KINERJA PEMASARAN PADA PT. BPR PRISMA DANA AMURANG. Jurnal Riset Ekonomi, Manajemen, Bisnis Dan Akuntansi. https://doi.org/10.35794/emba.v4i1.12343

Porter, M. (1990). Competitive advantage of nations. Competitive Intelligence Review. https://doi.org/10.1002/cir.3880010112

Porter, M. E. (1998). Competitive Advantage: Creating and Sustaining Superior Performance. In The Free. https://doi.org/10.1016/j.neubiorev.2009.11.015

Prajogo, D. I., \& Sohal, A. S. (2001). TQM and innovation: a literature review and research framework. Technovation, 21(9), 539558.

Pulendran, S., Speed, R., \& Widing, R. E. (2003). Marketing planning, market orientation and business performance. European Journal of Marketing, 37(3/4), 476-497.

Rahmawati, S., Darsono, D., \& Setyowati, N. (2019). Faktor-Faktor yang Mempengaruhi Kinerja Pemasaran pada Usaha Mikro Kecil dan Menengah Pangan Olahan di Kota Surakarta. Jurnal Ekonomi Pertanian Dan Agribisnis, 3(2), 325-335.

Rosli, M. M., \& Sidek, S. (2013). The Impact of Innovation on the Performance of Small and Medium Manufacturing Enterprises: Evidence from Malaysia. Journal of Innovation Management in Small \& Medium Enterprise. https://doi.org/10.5171/2013.885666

Salim, M., Alfansi, L., Febliansa, M. R., \& Widiyanti, M. (2020). GREEN AGILITY REVOLUTION VIA INNOVATION: A CASE STUDY. Journal of Security and Sustainability Issues. https://doi.org/10.9770/jssi.2020.9.3(17)

Santra, K. (20 C.E.). Management Science Letters 5. Managment Science Letters, 10(13), 3107-3118.

Shoham, A., Rose, G. M., \& Kropp, F. (2005). Market orientation and performance: A meta-analysis. Marketing Intelligence and Planning, 23(5), 435-454. https://doi.org/10.1108/02634500510612627

Sin, L. Y. M., Tse, A. C. B., Yau, O. H. M., Lee, J. S. Y., Chow, R., \& Lau, L. B. Y. (2000). Market Orientation and Business Performance. Journal of Global Marketing, 14(3), 5-29. https://doi.org/10.1300/j042v14n03_02

Slater, S. F., \& Narver, J. C. (1995). The Positive Effect of a Market Orientation. Journal of Business Research.

Slater, S. F., \& Narver, J. C. (2000). The positive effect of a market orientation on business profitability: A balanced replication. Journal of Business Research, 48(1), 69-73.

Song, M., \& Parry, M. E. (2009). The desired level of market orientation and business unit performance. Journal of the Academy of Marketing Science, 37(2), 144-160.

Susanto, P. (2012). Pengaruh Orientasi Pasar Pada Kinerja Perusahaan Kecil. Kajian Manajemen Bisnis, 1(September), 45-60.

Sutapa, S., Mulyana, M., \& Wasitowati, W. (2017). The role of market orientation, creativity and innovation in creating competitive advantages and creative industry performance. Jurnal Dinamika Manajemen, 8(2), 152-166.

Tjiptono, F. (2011). Strategi Pemasaran (ketiga). In Jurnal Ilmu Administrasi dan Organisasi.

Uncles, M. (2000). Market Orientation. In Australian Journal of Management. https://doi.org/10.1177/031289620002500201

Vargo, S. L., \& Lusch, R. F. (2008). Service-dominant logic: Continuing the evolution. Journal of the Academy of Marketing Science. https://doi.org/10.1007/s11747-007-0069-6

Xuan, V. N., Thu, N. T. P., \& Anh, N. T. (2020). Factors affecting support services in small and medium enterprises: Evidence from Vietnam small and medium information technology enterprises. Management Science Letters, 10(2), 303-312.

Yacob, S., Erida, E., Machpuddin, A., \& Alamsyah, D. P. (2021). A model for the business performance of micro, small and medium enterprises: Perspective of social commerce and the uniqueness of resource capability in Indonesia. Management Science Letters, $11,101-110$.

Yin, X., \& Zuscovitch, E. (1998). Yin1998.Pdf. Journal of Economic Behavior \& Organization, 35, 243-262. https://www.sciencedirect.com/science/article/abs/pii/S0167268198000572

Zaefarian, G., Forkmann, S., Mitręga, M., \& Henneberg, S. C. (2017). A Capability Perspective on Relationship Ending and Its Impact on Product Innovation Success and Firm Performance. Long Range Planning, 50(2), 184-199. https://doi.org/10.1016/j.lrp.2015.12.023

Zahra, S. A., Dharwadkar, R., \& George, G. (2000, May). Entrepreneurship in multinational subsidiaries: The effects of corporate and local environmental contexts. In Published in Conference Proceedings, Entrepreneurship, Academy of Management, Toronto, Canada, August (Vol. 2130, pp. 4-9).

Zhang, J., \& Zhu, M. (2016). Market orientation, product innovation and export performance: evidence from Chinese manufacturers. Journal of Strategic Marketing, 24(5), 377-397. https://doi.org/10.1080/0965254X.2015.1052538

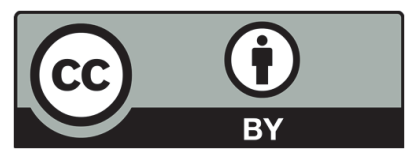

(C) 2021 by the authors; licensee Growing Science, Canada. This is an open access article distributed under the terms and conditions of the Creative Commons Attribution (CC-BY) license (http://creativecommons.org/licenses/by/4.0/). 